\title{
PROBLEM BASED LEARNING DENGAN KONTEKS ESD UNTUK MENINGKATKAN KETERAMPILAN BERPIKIR KRITIS DAN SUSTAINABILITY AWARENESS SISWA SMA PADA MATERI PEMANASAN GLOBAL
}

\author{
Kikit Anjar Agusti $^{\text {a) }}$, A.F.C. Wijaya ${ }^{\text {b) }}$, David Edison Tarigan ${ }^{\text {c) }}$ \\ Departemen Pendidikan Fisika FPMIPA UPI Jl. Dr. Setiabudi No 299, Bandung 40154 \\ Email: : ${ }^{\text {a) }}$ kikit@ $@$ student.upi.edu,${ }^{\text {b) }}$ agus.fany@upi.edu,${ }^{\text {c) }}$ davidtarigan@upi.edu
}

\begin{abstract}
Abstrak
Salah satu keterampilan yang harus dimiliki oleh siswa untuk menghadapi perkembangan abad-21 adalah keterampilan berpikir kritis. Keterampilan berpikir kritis penting bagi siswa untuk mendukung pembangunan berkelanjutan, yang juga merupakan agenda abad-21. Dalam hal ini, pendidikan merupakan gerbang untuk memperkenalkan pembangunan berkelanjutan dan melatihkan keterampilan berpikir kritis siswa. Salah satu caranya adalah dengan mengimplementasikan model pembelajaran yang di dalamnya diintegrasikan konteks Education for Sustainable Development (ESD). Oleh karena itu, penelitian ini bertujuan untuk mengetahui pengaruh implementasi model pembelajaran Problem Based Learning dengan konteks Education for Sustainable Development, dalam meningkatkan keterampilan berpikir kritis siswa dan juga mengetahui kesadaran siswa akan pembangunan berkelanjutan, terutama dalam isu pemansan global. Penelitian ini menggunakan one group pretest-posttest design dengan jumlah partisipan 31 siswa SMA Negeri di Kota Bandung. Instrumen yang digunakan dalam penelitian ini berupa pilihan ganda untuk mengukur keterampilan berpikir kritis siswa dan angket sustainability awareness untuk melihat profil kesadaran siswa akan pembangunan berkelanjutan. Hasil penelitian menunjukkan bahwa dengan penerapan model pembelajaran Problem Based Learning (PBL) yang disisipi konteks Education for Sustainable Development (ESD) dapat meningkatkan keterampilan berpikir kritis siswa dalam kategori sedang, sementara itu profil Sustainability Awareness siswa setelah kegiatan pembelajaran, tinggi dalam hal emosional, tetapi masih jarang dilakukan untuk kategori praktis.
\end{abstract}

Kata-kata kunci: PBL, Education for Sustainable Development, Keterampilan Berpikir Kritis.

\begin{abstract}
One of the skills that must be have by students to face the development of the 21 st century is critical thinking skills. Critical thinking skills are important for students to support sustainable development, which is also 21 st century agenda. In this case, education is a gateway to introducing sustainable development and training students' critical thinking skills. The way is to implement learning models which integrated by context of Education for Sustainable Development (ESD). Therefore, this study aims to determine the effect of implementing Problem Based Learning learning models with the context of Education for Sustainable Development, in improving students 'critical thinking skills and also for knowing students' awareness of sustainable development, especially in the issue of global warming. This study used one group pretest-posttest design with the participants is 31 high school students in Bandung. The instrument used in this study was multiple choice to measure students 'critical thinking
\end{abstract}


skills and sustainability awareness questionnaire to see the profile of students' awareness of sustainable development. The results showed that the implementation of the Problem Based Learning (PBL) with the context of Education for Sustainable Development (ESD) could improve students' critical thinking skills in the medium category, while the profile of Sustainability Awareness of students after learning activities is high in emotional terms, but still rarely done in practical categories.

Keywords: PBL, Education for Sustainable Development, Critical Thinking Skills.

\section{PENDAHULUAN}

Pada abad 21 ini, perkembangan ilmu pengetahuan dan teknologi (IPTEK) semakin meningkat dan akan terus mengalami perkembangan seiring berjalannya waktu. Oleh karena itu, siswa sebagai sumber daya manusia (SDM) yang akan terjun langsung untuk menghadapi perkembangan tersebut, tidak cukup jika hanya dibekali pengetahuan saja, tetapi juga harus dibekali dengan keterampilan yang menunjang. Hal ini menjadi tanggung jawab bidang pendidikan untuk menumbuhkan dan mengembangkan keterampilan yang dibutuhkan siswa. Keterampilan yang diperlukan untuk Pendidikan Abad 21 adalah Kreativitas, Berpikir Kritis, Komunikasi, dan Kolaborasi [1]. Keterampilan tersebut sesuai dengan yang tercantum dalam Peraturan Menteri Pendidikan Dan Kebudayaan Nomor 20 Tahun 2016 Tentang Standar Kompetensi Lulusan Pendidikan Dasar Dan Menengah yang menyebutkan bahwa kompetensi yang harus dimiliki siswa pada dimensi keterampilan adalah: 1) kreatif; 2) produktif; 3) kritis; 4) mandiri; 5) kolaboratif, dan 6) komunikatif [2].

Dari beberapa keterampilan yang harus dimiliki oleh siswa, berpikir kritis adalah salah satu keterampilan yang paling sering dibahas dalam dunia pendidikan, dan diyakini memainkan peranan penting dalam pemikiran logis, pengambilan keputusan, argumentasi, dan pemecahan masalah (Ennis, 1985; Facione, 1990; Halpern, 1998) [3][4][5]. Dimana pada zaman sekarang ini, banyak sekali permasalahan lokal maupun global yang perlu dikritisi tetapi informasi yang tersedia tidak sepenuhnya bisa digunakan, melainkan perlu di pilah terlebih dahulu mana yang akurat untuk dijadikan sebagai sumber informasi dan mana yang bisa dipertanggung jawabkan kebenarannya. Fisika sebagai salah satu ilmu sains yang berperan penting dalam perkembangan IPTEK tentu memiliki sudut pandang tersendiri untuk menanggapi masalah tersebut. Hanya saja untuk memecahkan permasalahan di zaman sekarang ini tidak cukup jika hanya dipandang dari satu sudut pandang ilmu. Tetapi perlu kita tinjau dari berbagai disiplin ilmu, supaya tindakan yang diambil tidak banyak merugikan aspek kehidupan lainnya. Seperti halnya Educational for Sustainable Development (ESD) yang dicetuskan oleh UNESCO. ESD yaitu belajar sepanjang hayat yang bertujuan untuk menginformasikan dan melibatkan penduduk agar aktif, kreatif juga memiliki keterampilan menyelesaikan masalah, saintifik, dan sosial literasi, lalu berkomitmen untuk terikat pada tanggung jawab pribadi dan kelompok yang mana tindakan ini akan menjamin kesejahteraan lingkungan secara ekonomi di masa depan[6]. ESD memandang masalah dengan berdasarkan pada tiga pilar yaitu: lingkungan, sosial dan ekonomi. Pilar tersebut tentunya memiliki keterkaitan dengan isu global, dan juga berkaitan dengan keberlanjutan hidup manusia. Sehingga dengan adanya konteks ESD ini diharapkan siswa akan memiliki sustainability awareness atau kesadaran akan keberlanjutan terutama dalam menghadapi permasalahan global, dan juga memikirkan secara kritis bagaimana cara untuk mengatasi suatu permasalahan dengan memerhatikan dampak yang akan ditimbulkan pada berbagai aspek kehidupan.

Sementara itu di lapangan, tidak sedikit guru yang masih menerapkan pembelajaran dengan metode konvensional yaitu belajar dengan menggunakan metode ceramah dimana guru menjadi satusatunya sumber belajar dan hanya terpaku pada buku bacaan. Hal ini akan membuat siswa cenderung lebih pasif, lebih banyak menerima informasi dibandingkan mencari informasi dan juga berdampak pada pencapaian hasil Programme for International Student Assesment (PISA). Pada tahun 2015, Indonesia menempati peringkat ke 64 dari 72 negara peserta. Dengan poin 403, beda 153 poin dengan negara yang menduduki peringkat pertama [7]. Hasil ini menunjukkan bahwa Indonesia masih jauh tertinggal dari negara-negara berkembang lainnya. Sehingga perlu adanya peningkatan 
kualitas pembelajaran di sekolah yang salah satunya dengan melatihkan keterampilan berpikir kritis dan juga perlu adanya kajian terhadap permasalahan-permasalahan global yang sedang terjadi.

Sedangkan menurut Peraturan Menteri Pendidikan Dan Kebudayaan Nomor 22 Tahun 2016 Tentang Standar Proses Pendidikan Dasar Dan Menengah menyebutkan bahwa prinsip pembelajaran yang digunakan harus diubah dari peserta didik diberi tahu menuju peserta didik mencari tahu; dan dari guru sebagai satu-satunya sumber belajar menjadi belajar berbasis aneka sumber belajar. Dan model pembelajaran yang disarankan oleh permendikbud adalah model pembelajaran discovery, inquiry, project based learning dan problem based learning [8]. Maka untuk meningkatkan kemampuan berpikir kritis siswa, seharusnya guru harus menerapkan model pembelajaran yang menuntut siswa untuk aktif, mencari tahu sendiri bagaimana cara menghadapi atau menyelesaikan suatu permasalahan dalam pembelajaran. Menurut Nafiah dan Suyanto (2006) Salah satu model pembelajaran yang dapat meningkatkan keterampilan berpikir kritis siswa adalah model PBL [9]. PBL merupakan suatu pendekatan pembelajaran yang menggunakan masalah dunia nyata sebagai suatu konteks bagi peserta didik untuk belajar tentang cara berpikir kritis dan keterampilan pemecahan masalah, serta untuk memperoleh pengetahuan dan konsep yang esensial dari materi pelajaran. PBL merupakan pembelajaran berdasarkan teori kognitif yang didalamnya termasuk teori belajar konstruktivisme, menurut teori konstruktivisme, keterampilan berpikir dan memecahkan masalah dapat dikembangkan jika peserta didik melakukan sendiri, menemukan, dan memindahkan kekomplekan pengetahuan yang ada [9]. Namun dalam pembelajaran di sekolah seharusnya juga ditanamkan Sustainability awareness untuk mendukung pembangunan berkelanjutan (ESD). Sustainability Awareness merupakan salah satu penunjang keterlaksanaan konsep pembangunan berkelanjutan yang menjadi salah satu inovasi baru dari pendidikan yang dimulai dari Education for Sustainable Development. Salah satu materi dalam pembelajaran fisika yang bisa disisipkan konteks ESD yaitu Pemanasan Global. Dimana materi Pemanasan Global dapat menunjang kehidupan dimasa yang akan datang. Sehingga diharapkan siswa lebih sadar akan permasalahan seputar pemanasan global. Dengan demikian, penulis mencoba melakukan penelitian dengan judul "Penerapan model pembelajaran Problem Based Learning dengan konteks Education for Sustainable Development untuk meningkatkan keterampilan berpikir kritis dan Profil Sustainability Awareness siswa pada materi pemanasan global".

\section{METODOLOGI}

Penelitian yang dilakukan adalah penelitian kuantitatif dengan jenis penelitian yang digunakan adalah pre-experimental designs dan bentuk penelitian yang digunaka adalah one group pretestposttest designs. Pada awalnya, siswa diberikan soal pretest untuk mengukur keterampilan berpikir kritis pada materi pemanasan global, kemudian siswa diberikan treatment dengan mengimplementasikan model pembelajaran problem based learning dengan konteks ESD dan setelah treatment tersebut selesai, siswa diberikan posttest untuk mengukur keterampilan berpikir kritis pada materi pemanasan global. Populasi dalam penelitian ini adalah siswa kelas XI SMA di SMA Y kemudian sample diambil dengan cara menggunakan Convenience sampling pada siswa kelas XI SMA di SMA Y pada semester genap tahun ajaran 2018/2019.

Bentuk instrumen tes yang digunakan untuk melihat peningkatan keterampilan berpikir kritis siswa adalah soal pilihan ganda yang disusun berdasarkan aspek keterampilan berpikir kritis menurut Facione. Jumlah soal yang digunakan adalah sebanyak 20 butir soal dengan materi pemanasan global. Kemudian dianalisis menggunakan nilai $n$-gain. Berikut tabel sebaran aspek keterampilan berpikir kritis dalam instrumen keterampilan berpikir kritis. 
TABEL 1. Sebaran Aspek Keterampilan Berpikir Kritis dalam Instrumen Keterampilan Berpikir Kritis.

\begin{tabular}{cc}
\hline Aspek Keterampilan Berpikir Kritis & Nomor Soal \\
\hline Menafsirkan & $1,2,15,8$ \\
Menginferensi & $4,12,19,20$ \\
Menjelaskan & $3,5,10,11$ \\
Menganalisa & $6,9,16,17$ \\
Mengevaluasi & $13,14,7,18$ \\
\hline
\end{tabular}

Selanjutnya, untuk mengetahui profil sustainability awareness siswa, digunakan angket persepsi siswa yang berjumlah 15 butir pernyataan dengan menggunakan skala guttman dan pilihan jawaban "ya" dan "tidak".

\section{HASIL DAN PEMBAHASAN}

\section{Peningkatan Keterampilan Berpikir Kritis}

Peningkatan keterampilan berpikir kritis siswa setelah penerapan model pembelajaran problem based learning dengan konteks ESD, dapat dilihat dari perhitungan skor $n$-gain $\langle\mathrm{g}\rangle$ berdasarkan rata-rata pretest dan posttest. Berikut rekapitulasi peningkatan keterampilan berpikir kritis siswa.

TABEL 2. Rekapitulasi Hasil Tes Peningkatan Keterampilan Berpikir Kritis Siswa.

\begin{tabular}{llll}
\hline Rata-Rata Pretest & Rata-Rata Posttest & $\langle$ g $>$ & Kategori \\
\hline 61,77 & 75,97 & 0,37 & Sedang \\
\hline
\end{tabular}

Berdasarkan tabel 2, nilai $n$-gain dari hasil tes keterampilan berpikir kritis siswa secara keseluruhan adalah sebesar 0,37 dengan kategori sedang. Sehingga dapat dikatakan bahwa pada umumnya keterampilan berpikir kritis siswa mengalami peningkatan setelah diterapkannya model pembelajaran Problem Based Learning (PBL) dengan konteks ESD (Education for Sustainable Development). Sesuai dengan penelitian yang telah dilakukan sebelumnya dengan judul "Penerapan Model Pembelajaran PBL Untuk Meningkatkan Penguasaan Konsep Dan Keterampilan Berpikir Kritis Siswa Pada Konsep Elastisitas Dan Hukum 1 Hooke Di SMA Negeri Unggul Harapan Persada"(Muslim,2015) bahwa penerapan model pembelajaran PBL dapat meningkatkan penguasaan konsep dan keterampilan berpikir kritis siswa. Implementasi Pembelajaran Berbasis Masalah atau PBL dapat meningkatkan keterampilan berpikir kritis karena diamati bahwa siswa menjadi lebih aktif dan dapat menggunakan kemampuan berpikir mereka, siswa tidak hanya pasif dalam menerima penjelasan yang disampaikan oleh guru dan dalam Pembelajaran Berbasis Masalah, siswa dituntut untuk secara aktif mengembangkan keterampilan berpikir mereka untuk merumuskan masalah dan menemukan solusi dalam memecahkan masalah, sehingga dapat mengembangkan kemampuan keterampilan berpikir kritis mereka. Untuk mengetahui peningkatan keterampilan berpikir kritis siswa secara lebih rinci, maka berikut peningkatan keterampilan berpikir kritis dilihat dari setiap aspeknya adalah sebagai berikut. 


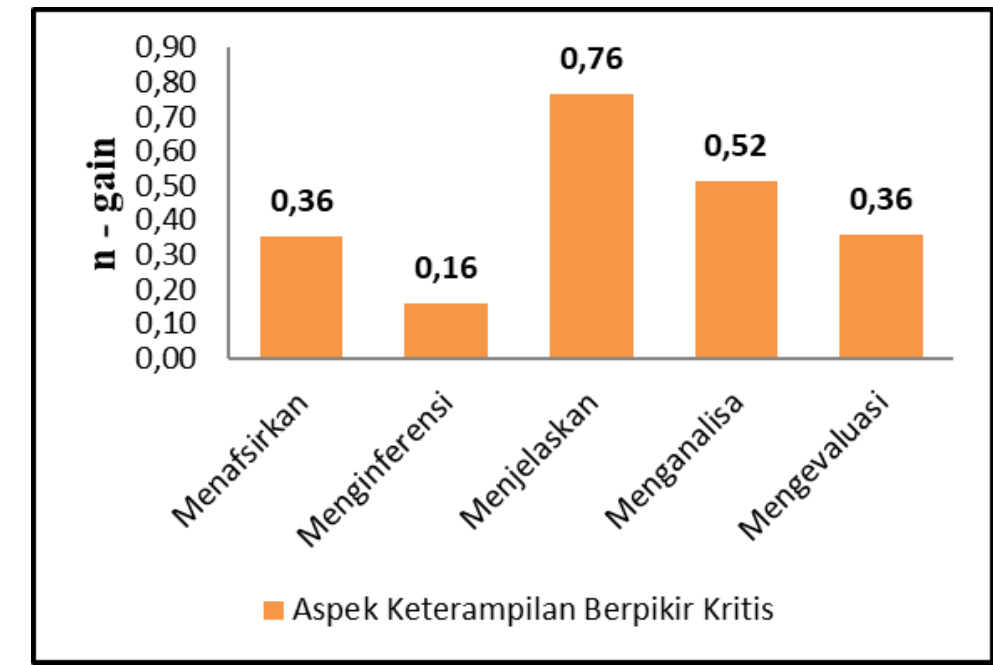

GAMBAR 1. Diagram Peningkatan Keterampilan Berpikir Kritis Siswa pada Setiap Aspek.

Berdasarkan diagram diatas, terlihat nilai $n$-gain yang di dapat untuk setiap aspek, besarnya bervariasi. $\mathrm{N}$-gain terbesar yaitu 0,76 dengan kategori tinggi untuk aspek menjelaskan dan $n$-gain terkecil yaitu 0,16 dengan kategori rendah untuk aspek menginferensi. Sedangkan untuk aspek menafsirkan, menganalisa dan mengevaluasi nilai n-gain yang diperoleh termasuk ke dalam kategori sedang. Sebenarnya, pada awalnya siswa sudah mempunyai aspek menginferensi yang cukup bagus, namun setelah diterapkan model pembelajaran problem based learning dengan konteks ESD peningkatan yang terjadi relatif kecil. Sehingga inilah yang menyebabkan $n$-gain untuk aspek menginferensi termasuk ke dalam kategori rendah.

Setelah merefleksi pada keterlaksanaan pembelajaran yang dilakukan, aspek menginferensi yang dilatihkan perbandingannya lebih sedikit dibandingkan dengan aspek menjelaskan. Aspek menginferensi hanya dilatihkan 3 kali dalam 2 pertemuan, sementara aspek menjelaskan dilatihkan lebih banyak dari itu. Ternyata hal tersebut menyebabkan peningkatan keterampilan berpikir kritis untuk aspek menginferensi lebih sedikit dibandingkan dengan peningkatan pada aspek menjelaskan.

\section{Profil Sustainability Awareness Siswa}

Berikut ini rekapitulasi hasil tanggapan responden terhadap angket sustainability awareness.

TABEL 3. Rata-rata Respon Positif pada Pernyataan Sustainability Awareness

\begin{tabular}{llc}
\hline Pernyataan & Persentase & $\begin{array}{l}\text { Standar } \\
\text { Deviasi }\end{array}$ \\
\hline Sustainability practice awareness & & 0,51 \\
Saya selalu membahas masalah lingkungan dengan teman-teman saya & $48 \%$ & 0,34 \\
Saya mengomposkan sisa makanan menjadi pupuk & $13 \%$ & 0,51 \\
Saya tidak menggunakan kantong plastik untuk membungkus barang & $48 \%$ & 0,5 \\
Saya menyampaikan informasi tentang lingkungan kepada anggota keluarga & $61 \%$ & 0,5 \\
saya & $58 \%$ & 0,18 \\
Saya mengikuti dalam kegiatan penyadaran lingkungan di sekolah & & 0 \\
Behavioral and attitude awareness & $97 \%$ \\
Saya membaca tentang isu lingkungan di media massa & $100 \%$ & 0,4 \\
Saya menghargai keanekaragaman hayati & $81 \%$ & 0,51 \\
Saya peduli tentang asap yang berasal dari kendaraan-kendaraan & $48 \%$ & 0,34 \\
Saya mencoba mengurangi jumlah sampah di rumah dengan mengumpulkan \\
bahan yang bisa didaur ulang & & 0,18 \\
Saya menghidupkam lampu di rumah pada siang hari & $87 \%$ & 0,18 \\
Saya menghemat pemakaian air bersih & $97 \%$ & $97 \%$
\end{tabular}




\section{Emotional Awareness}

Saya peduli dengan masalah lingkungan di tempat saya

Saya merasa kecewa dengan polusi udara

Saya merasa kecewa dengan polusi sungai

$81 \%$

$97 \%$

$94 \%$

$94 \%$

0,4

0,18

0,25

Saya menyadari tanggung jawab saya terhadap lingkungan
0,25

Berdasarkan tabel diatas, respon siswa paling banyak adalah $100 \%$ pada pernyataan "saya menghargai keanekaragaman hayati", hal tersebut menunjukkan bahwa tingginya Sustainability Awareness siswa. Kemudian respon paling banyak berikutnya adalah pada pernyataan "saya membaca isu lingkungan di media masa", "saya merasa kecewa dengan polusi udara" dan "saya menghemat pemakaian air bersih" dengan ratarata persentase 97\%. Hal tersebut menunjukkan bahwa Sustainability Awareness siswa pada isu lingkungan, polusi udara dan upaya mereka dalam menghemat air bersih sangat tinggi. Sementara itu, respon siswa paling sedikit adalah pada pernyataan "Saya mengomposkan sisa makanan menjadi pupuk" dengan rata-rata persentase $13 \%$ menyatakan bahwa masih kurangnya kesadaran siswa dalam mengolah limbah sehingga bisa dikatakan bahwa sustainability awareness siswa dalam hal ini masih kurang.

Berdasarkan tabel di atas kategori yang pertama yaitu Sustainability practice awareness terlihat bahwa persentase responden untuk perilaku tersebut adalah 45,81\% yang artinya perilaku tersebut yang tertera dalam pernyataan pada angket masih jarang dilakukan oleh sebagian besar jumlah siswa. Sustainability practice awareness atau upaya sadar dalam menjalankan keberlanjutan yang jarang dilakukan oleh siswa adalah kegiatan seperti membahas isu lingkungan dengan teman, mengomposkan sisa makanan menjadi pupuk, menggunakan kantong plastik, membahas mengenai masalah lingkungan dengan keluarga dan juga melakukan aksi untuk mengatasi permasalahan lingkungan. Perilaku-perilaku yang dimuat dalam pernyataan pada angket adalah merupakan ciri dari sikap yang akan ditunjukkan apabila seseorang sudah mengerti tentang konsep keberlanjutan.

Kategori yang kedua yaitu Behavioral and attitude awareness atau sikap peduli terhadap lingkungan dengan presentase sebesar $84,41 \%$ dari jumlah seluruh siswa yang artinya siswa selalu peduli terhadap lingkungan. Behavioral and attitude awareness atau sikap peduli terhadap lingkungan sering atau selalu dilakukan siswa adalah kegiatan seperti membaca isu lingkungan di media massa, menghargai keanekaragaman hayati, peduli terhadap asap kendaraan bermotor, mendaur ulang sampah rumah tangga, tidak menyalakan lampu disiang hari dan mengurangi pemakaian air bersih.

Kategori yang ketiga yaitu Emotional awareness atau kepedulian terhadap lingkungan secara emosi termasuk sikap atau perilaku yang sering atau selalu dilakukan oleh seluruh siswa, terlihat pada tabel di atas persentase jumlah respon siswa untuk semua pernyataan sikap Emotional awareness adalah sebesar 91.13\%, dengan demikian dapat dikatakan bahwa secara emosional siswa memiliki kepedulian tinggi terhadap lingkungannya. Kepedulian terhadap lingkungan secara emosional yaitu seperti merasa peduli dengan permasalahan lingkungan, merasa kecewa dengan polusi yang ada di udara dan sungai dan sadar akan tanggung jawab manusia terhadap lingkungan. Sehingga, Sustainability awareness atau kepedulian berkelanjutan siswa berdasarkan kategorinya yang paling baik hanya peduli terhadap lingkungan secara emosional dan masih jarang kepeduliannya ditunjukkan dengan sikap apalagi secara keberlanjutan dilakukan terus menerus.

\section{SIMPULAN}

Berdasarkan pemaparan hasil penelitian di atas, dapat disimpulkan bahwa model pembelajaran problem based learning dengan konteks ESD (Educational for Sustainable Development) dapat dijadikan alternatif untuk meningkatkan keterampilan berpikir kritis siswa. Dan berdasarkan tiga kategori Sustainability Awareness siswa hanya memiliki kesadaran terhadap nilai keberlanjutan pada tingkat emosi dan masih kurang dalam mempraktekannya dalam kehidupan sehari-hari. Sikap Sustainability awareness dapat mendukung konsep pendidikan berkelanjutan atau ESD sehingga dengan hasil profil Sustainability awareness dengan kategori tinggi dapat dikatakan bahwa sikap siswa yang diteliti sudah mendukung terhadap konsep ESD tersebut. Hal tersebut sesuai dengan yang dikatakan oleh Hasan (2010) bahwa yang dapat mendukung konsep ESD yaitu sikap Sustainability awareness yang tinggi [10]. 


\section{REFERENSI}

[1] Bialik, M., \& Fadel, C. "Skills for the 21st Century: What Should Students Learn?. Boston, Center for Curriculum Redesign, 2015.

[2] Peraturan Menteri Pendidikan dan Kebudayaan Republik Indonesia Nomor 20 Tahun 2016 Tentang Standar Kompetensi Lulusan Pendidikan Dasar Dan Menengah

[3] Ennis, R. H. “A Logical Basic For Measuring Critical Thinking Skills”. Educational Leadership. 1985. 43(2), 44-48.

[4] Facione, P. A. "Critical Thinking: A Statement of Expert Consensus for Purposes of Educational Assesment and Instruction". Fullerton: ERIC.1990.

[5] Halpern, D. F. "Teaching Critical Thinking for Transfer Across Domains". American, Psycologist , 1998. 53(4),449-455.

[6] UNESCO. "Education for Sustainable Development Goals". France: UNESCO. 2015.

[7] OECD. "PISA 2015 Results (Volume I): Excellence and Equity in Education, PISA, OECD", Publishing: Paris. 2016.

[8] Peraturan Menteri Pendidikan Dan Kebudayaan Nomor 22 Tahun 2016 Tentang Standar Proses Pendidikan Dasar Dan Menengah

[9] Nafiah, Y. N. "Penerapan Model Problem-Based Learning Untuk Meningkatkan Keterampilan Berpikir Kritis Dan Hasil Belajar Siswa". Jurnal Pendidikan Vokasi, 2014. 4 (1), 130 .

[10] Hasan, A. Ariffin, T. Sulaiman, S, “ The status on the level of environmental awareness in the concept of sustainable development amongst secondary school students", 2010, Faculty of Education, UniversitiKebangsaan Malaysia, 43600 Bangi, Selangor Malaysia.: Procedia Social and Behavioral Sciences 2 (2010) 1276-1280 
